\title{
ANALISIS KINERJA, NILAI TAMBAH DAN MITIGASI RISIKO RANTAI PASOK AGROINDUSTRI BAWANG MERAH
}

\section{ADDED VALUE, PERFORMANCE ANALYSIS AND RISK MITIGATION OF THE SHALLOT AGROINDUSTRY SUPPLY CHAIN}

\author{
Ayu Resti Pamungkassari ${ }^{1 *}$, Marimin' $^{2)}$, dan Indah Yuliasih ${ }^{2)}$ \\ Departemen Teknologi Industri Pertanian, Fakultas Teknologi Pertanian, Institut Pertanian Bogor \\ Jl. Raya Darmaga, Kampus IPB Darmaga, Bogor 16680, Jawa Barat, Indonesia \\ *E-mail: ayurestipamungkas@gmail.com
}

Makalah: Diterima 3 November 2017; Diperbaiki 18 Maret 2018; Disetujui 25Maret 2018

\begin{abstract}
The supply chain of shallot agroindustry is in urgent situation owing to theimbalance risk and addedvalue distribution of the actors in the supply chain. The purposes of this research were (1) to identify the mechanism and performance of shallot supply chain; (2) to measure the added-value of supply chain actors; (3) to identify and mitigate the risk in shallot supply chain; and (4) to select the strategy to improve the performances, added-value, and risk mitigation ofshallot supply chain. Supply Chain Operations ReferenceAnalytical Hierarchy Process (SCOR-AHP)wereemployed to measure the performance of shallot supply chain.Hayami method was used to analyze the added-value.House of Risk (HOR)was used to identify and mitigate the risk, while the strategies for the improvements were formulated using Analytic Network ProcessBenefit Opportunity Cost Risk analysis (ANP-BOCR) method. Analysis on the supply chain performance showed those classified as below average were farmer (75.38\%), first collector (74.43\%), and industry (74.79\%), whereasthe second collector hadagood performance (91.97\%). Added-value ratios were for the industry of $53.75 \%$, farmer of $46.06 \%$, first collector of $8.88 \%$, and second collector of $5.39 \%$. Total effectivity measurement of risk mitigation to prioritized risk agent resulted the farmer had11 preventive actions, the collectors had 9 and the industry had8. The supply chain evaluation resulted in four alternatives for the improvement strategy of the performance, added-value and risk mitigation.The best alternative with the highest BO/CR ratio was the implementation of the SOP of proper cultivation and post-harvesting method.
\end{abstract}

Keywords: shallot agroindustry, risk mitigation, supply chain, value added

\section{ABSTRAK}

Rantai pasok agroindustri bawang merah berada dalam titik kritis karena distribusi risiko dan nilai tambah pada pelaku rantai pasok tidak seimbang. Penelitian ini bertujuan(1) mengidentifikasi mekanisme dan mengukur kinerja rantai pasok, (2) melakukan perhitungan nilai tambah pada pelaku rantai pasok, (3) mengidentifikasi dan memitigasi risiko rantai pasok, dan (4) pemilihan altenatif strategi peningkatan kinerja, nilai tambah dan mitigasi risiko pada rantai pasok. Metode Supply Chain Operatins Reference-Analytical Hierarchy Process (SCOR-AHP) digunakan untuk mengukur kinerja rantai pasok. Metode Hayami digunakan untuk melakukan perhitungan nilai tambah. Metode House of Risk (HOR) digunakan untuk identifikasi resiko dan mitigasi resiko. Metode Analytic Network Process-Benefit Opportunity Cost Risk (ANP-BOCR) digunakan untuk perumusan dan pemilihan strategi peningkatan kinerja, nilai tambah dan mitigasi risiko. Analisiskinerja rantai pasok agroindustri bawang merah menunjukkan bahwa kinerja di tingkat petani (75,38\%), pengumpul 1 $(74,43 \%)$, industri $(74,79 \%)$ terklasifikasikan dalam kurang baik sedangkan kinerja di tingkat pengumpul 2 $(91,97 \%)$ masuk klasifikasi kinerja yang baik. Analisis nilai tambah menemukan bahwa rasio nilai tambah di tingkat petani sebesar 46,06\%, pengumpul 1sebesar 8,88\%, pengumpul 2 sebesar 5,39\% dan industri sebesar $53,75 \%$. Perhitungan total efektivitas aksi mitigasi pada sumber risiko prioritas menghasilkan 11 aksi mitigasi di tingkat petani, 9 aksi mitigasi ditingkat pengumpul dan 8 aksi mitigasi ditingkat industri. Evaluasi rantai pasok menghasilkan empat alternatif strategi untuk peningkatan kinerja, nilai tambah dan mitigasi risiko.Alternatif terbaik dengan nilai rasio $B O / C R$ tertinggi adalah penerapan SOP budidaya dan pascapanen yang tepat.

Kata kunci : agroindustri bawang merah, mitigasi risiko, nilai tambah, rantai pasok

\section{PENDAHULUAN}

Bawang merah adalah salah satu komoditas sayuran yang banyak dikonsumsi oleh masyarakat Indonesia sebagai bahan rempah dalam masakan.
Pertumbuhan konsumsi rata-rata bawang merah mencapai 5,31\% (Kementan, 2015). Setiap tahun konsumsi permintaan bawang merah mengalami peningkatan kecuali pada tahun 2013 mengalami penurunan. Penurunan konsumsi terjadi karena harga

*Penulis Korespodensi 
bawang merah mengalami kenaikan sebesar 13,84\% sehingga menyebabkan penurunan daya beli konsumen untuk mengkonsumsi bawang merah (Kemendag, 2013).

Peningkatan permintaan terjadi seiring bertambahnya penduduk tetapi jumlah pasokan berfluktuatif karena sifat produk yang musiman. Permintaan yang meningkat namun distribusi pasokan tidak merata menyebabkan kenaikan harga karena permintaan tidak sesuai dengan penawaran. Kondisi tersebut menyebabkan terjadinya gejolak pada harga karena adanya kesenjangan (gap) antara pasokan dan permintaan sehingga menyebabkan fluktuasi harga antar waktu (BAPPENAS, 2015). Fluktuasi harga yang tidak stabil menyebabkan bawang merah menjadi salah satu komoditas penyumbang inflasi nasional sebesar $0,176 \%$ (BPS, 2016).

Komoditas pertanian mempunyai karakteristik khusus diantaranya mudah rusak, kamba, dan musiman hal ini menyebabkan kompleksitas dalam merancang sistem rantai pasok (Marimin dan Setiawan, 2010). Karakteristik khusus tersebut berpengaruh dalam proses produksi pertanian. Risiko ketidakpastian produksi merupakan penyebab fluktuasi pada harga bawang merah. Risiko ketidakpastian musim dan harga akan mempengaruhi kinerja rantai pasok sehingga diperlukan adanya strategi penanganan risiko untuk mengurangi terjadinya kerugian atau ketidakpastian risiko (Manuj dan Mentzer, 2008). Strategi yang dapat dilakukan yaitu dengan memitigasi risiko pada rantai pasok agroindustri bawang merah. Menurut Septiani (2016) mitigasi risiko merupakan upaya penanganan risiko untuk mengurangi kemungkinan terjadinya risiko dan meminimalisir dampak terjadinya risiko. Risiko-risiko dalam rantai pasok agroindustri bawang merah perlu ditanggulangi untuk mengurangi kerugian sehingga tercipta keberlanjutan rantai pasok.

Hasil pengamatan awal di lapangan terindikasi beberapa permasalahan yang terjadi pada rantai pasok agroindustri bawang merah. Distribusi nilai tambah dan risiko pada pelaku rantai pasok tidak seimbang. Petani sebagai pelaku utama dalam rantai pasok memiliki risiko tertinggi yaitu kegagalan panen akibat ketidakpastian musim. Hasil penelitian yang dilakukan oleh Insani dan Perdana (2014), ketahui bahwa pada tingkat petani teridentifikasi sumber risiko sebanyak 14 dan kejadian risiko sebanyak 21 jumlah tersebut lebih banyak dibandingkan dengan pelaku lainnya. Salah satu sumber risiko dengan tingkat keparahan tertinggi dengan nilai 9 adalah risiko kegagalan panen (Insani dan Perdana, 2014).

Pengukuran rantai pasok dilakukan melalui analisis terhadap proses bisnis perusahaan meliputi analisis kinerja dan nilai tambah rantai pasok yang berperan dalam menciptakan kondisi perbaikan dan pengurangan risiko (Laudon dan Laudon, 2007). Analisis dan evaluasi rantai pasok akan memberikan informasi mengenai permasalah yang terdapat dalam rantai pasok. Berdasarkan hasil analisis kinerja dan nilai tambah, dilakukan identifikasi risiko penyebab rantai pasok kurang optimal serta menentukan arah perbaikan rantai pasok agroindustri bawang merah yang terintegrasi dari hulu ke hilir secara kontinu, efektif, dan efisien (Marimin dan Maghfiroh, 2010). Penelitian ini akan menghasilkan analisis terkait kinerja, nilai tambah, strategi mitigasi risiko dan strategi peningkatan dalam rantai pasok agroindustri bawang merah sehingga dapat mencapai keberlanjutan. Analisis ini akan memberikan masukan strategi bagi pelaku dalam rantai pasok agroindustri bawang merah dalam menghadapi permasalah yang ada.

Secara khusus, tujuan penelitian ini adalah sebagai berikut: 1) mengidentifikasi mekanisme dan mengukuran kinerja rantai pasok agroindustri bawang merah; 2) menghitung nilai tambah pelaku rantai pasok; 3) mengidentifikasi risiko dan memilih alternatif upaya mitigasi risiko dari sumber risiko pada pelaku rantai pasok; 4) pemilihan alternatif strategi peningkatan kinerja, nilai tambah dan mitigasi risiko rantai pasok.

\section{METODE PENELITIAN}

Penelitian ini dilaksanakan di sekitar Kabupaten Brebes sebagai sentra bawang merah dimulai pada bulan Agustus-September 2016 dan bulan April-Mei 2017. Teknik pengambilan sampel dalam penelitian ini adalahnon probability sampling. Sampel yang diambil berdasarkan beberapa kriteria tertentu yang telah ditetapkan berdasarkan pada tujuan dari penelitian yang akan dicapai. Penelitian ini menggunakan responden petani, pengumpul, industri dan pakar baik dari praktisi maupun akademisi yang berperan dalam memberikan penilaian dan saran perbaikan terhadap permasalahan dalam rantai pasok. Tahapan penelitian yang dilakukan meliputi identifikasi rantai pasok, pengukuran kinerja rantai pasok, analisis nilai tambah, identifikasi dan mitigasi risiko, dan perumusan strategi peningkatan kinerja, nilai tambah dan mitigasi risiko. Tahapan penelitian mengacu pada metodologi pemecahan masalah menggunakan pendekatan sistem (Marimin 2008). Validasi yang dilakukan dalam penelitian ini dilakukan melalui pakar dengan menggunakan kuesioner. Verifikasi dilakukan dengan menggunakan Microsoft Excel untuk agregasi pendapat pakar dan software Super Decisions untuk analisis $B O / C R$. Tahapan penelitian dapat dilihat pada Gambar 1. 


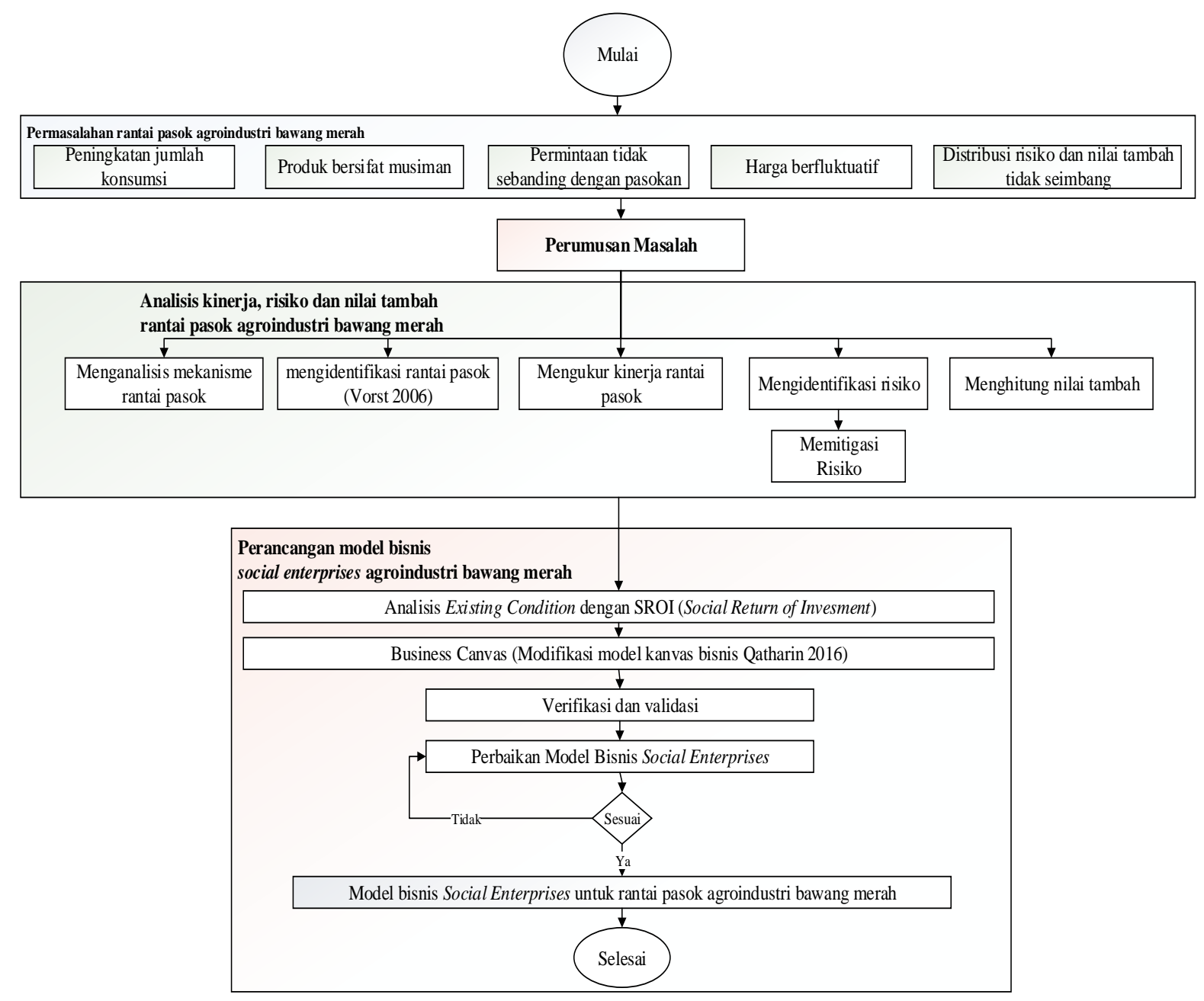

Gambar 1. Tahapan penelitian

\section{Identifikasi Rantai Pasok Agroindustri Bawang} Merah

Rantai pasok agroindustri bawang merah dianalisis menggunakan identifikasi empat elemen rantai pasok. Empat elemen dasar rantai pasok yang saling terkait yaitu elemen struktur, proses bisnis, manajemen, dan sumber daya rantai pasok (Vorst, 2006). Pada proses bisnis, Chopra dan Meindl (2013) menjelaskan bahwa proses-proses dalam rantai pasok dapat diidentifikasi dari sudut pandang tinjauan siklus yang dibagi dalam beberapa rangkaian siklus dan tinjauan dorong/tarik (push/pull view).

\section{Pengukuran Kinerja Rantai Pasok}

Pengukuran kinerja dilakukan dengan menggunakan model SCOR pada lima proses bisnis yang didekomposisi menjadi beberapa level dalam bentuk hierarki. Pengukuran kinerja rantai pasok dapat membantu perusahaan dalam mencapai tujuan yang telah dirumuskan sebelumnya berdasarkan strategi pencapaian tujuan yang telah ditetapkan perusahaan (Agami et al., 2011). Sistem pengukuran kinerja rantai pasok diperlukan untuk melakukan monitoring dan pengendalian, mengkomunikasikan tujuan organisasi ke fungsi-fungsi rantai pasokan, mengetahui posisi relatif terhadap pesaing dan menetukan arah perbaikan untuk menciptakan daya saing dan merupakan kebutuhan yang fundamental dalam perusahaan atau organisasi (Rachman, 2013). Proses bisnis rantai merupakan serangkaian aktivitas bisnis yang terstruktur dan terukur untuk menghasilkan output tertentu bagi konsumen.Pada setiap proses bisnis, metrik pengukuran kinerja tersebut memiliki tingkat kepentingan (bobot) yang berbeda, tergantung pada karakteristik proses bisnisnya (Palma-Mendoza et al., 2014).

Proses bisnis dalam penelitian mencakup level satu meliputi perencanaan, pengadaan, budidaya, pengolahan, dan pengiriman. Level 2 mencakup peningkatan nilai tambah, mitigasi risiko dan peningkatan produktivitas. Level 3 mencakup reliabilitas, responsivitas, agilitas dan biaya. Level 4 mencakup pemenuhan pesanan, kinerja pengiriman, kesesuaian dengan standar mutu, siklus pemenuhan pesanan, fleksibilitas rantai pasok, penyesuaian rantai pasok atas, penyesuaian rantai pasok bawah, biaya perawatan dan biaya pengolahan. Matriks kinerja disusun berdasarkan SCOR 11.0 oleh SCC (2012) dan pembobotannya dengan metode AHP menggunakan bantuan software Expert Choice 11 (www.expertchice.com). 


\section{Perhitungan Nilai Tambah Rantai Pasok}

Perhitungan dan analisis nilai tambah pada pelaku rantai pasok agroindustri bawang merah dilakukan dengan Metode Hayami. Nilai tambah dihitung dengan memperhatikan interaksi antar pelaku sesuai dengan tujuan masingmasing (Hidayat et al., 2012). Nilai tambah dan keuntungan dalam rantai pasok sangat menentukan kondisi finansial dan keunggulan bersaing proses bisnis tersebut (Frumkin dan Keating, 2011) dan menjadikan infomasi ini sangat penting untuk diketahui. Informasi nilai tambah juga diperlukan untuk mengetahui relasi yang kompleks dalam rantai pasok dan menentukan performa setiap stakeholder dalam rantai pasok (Rich et al., 2011; El-Sayed et al., 2015).

\section{Model Identifikasi dan Mitigasi Risiko}

Manajemen risiko merupakan suatu upaya untuk menyusun strategi dalam menghadapi risiko dalma rantai pasok. Manajemen risiko rantai pasok dengan serius memperhatikan sumber-sumber risiko sepanjang rantai pasok dan cara menghadapi atau minimasi risiko tersebut (Kamalahmadi dan Parast, 2016). Penelitian ini menggunakan metode HOR (House of Risk) untuk mengidentifikasi risiko dan pemilihan aksi mitigasi risiko pada rantai pasok agroindustri bawang merah. Model ini merupakan sebuah framework yang mengintegrasikan antara metode FMEA (Failure Mode and Effect Analysis) dan metode HOQ (House of Quality) (Pujawan dan Geraldine, 2009). Diagram alir metode HOR tertera pada Gambar 2.

\section{Pemilihan Alternatif Strategi Peningkatan Kinerja, Nilai Tambah dan Mitigasi Risiko} Pemilihan alternatif strategi untuk peningkatan kinerja rantai pasok bawang merah secara berkelanjutan dilakukan dengan menggunakan metode ANP (Analytical Networking Process), didasarkan pada kriteria utama menggunakan analisis BOCR (benefit, opportunity, cost dan risk) dengan kriteria keberlanjutan berupa teknologi, sosial, ekonomi, dan lingkungan, kemudian di dekomposisi menjadi subkriteriasubkriteria untuk pemilihan alternatif. Perumusan alternatif strategi peningkatan dilakukan dengan penilaian bobot yang paling tinggi berdasarkan analisis $B O / C R$ untuk mengetahui tingkat kepentingannya. Pengolahan data yang diperoleh berdasarkan perbandingan berpasangan, dilakukan dengan bantuan software Superdecisions 2.2.6 dan agregasi pendapat pakar menggunakan Microsoft Excel.

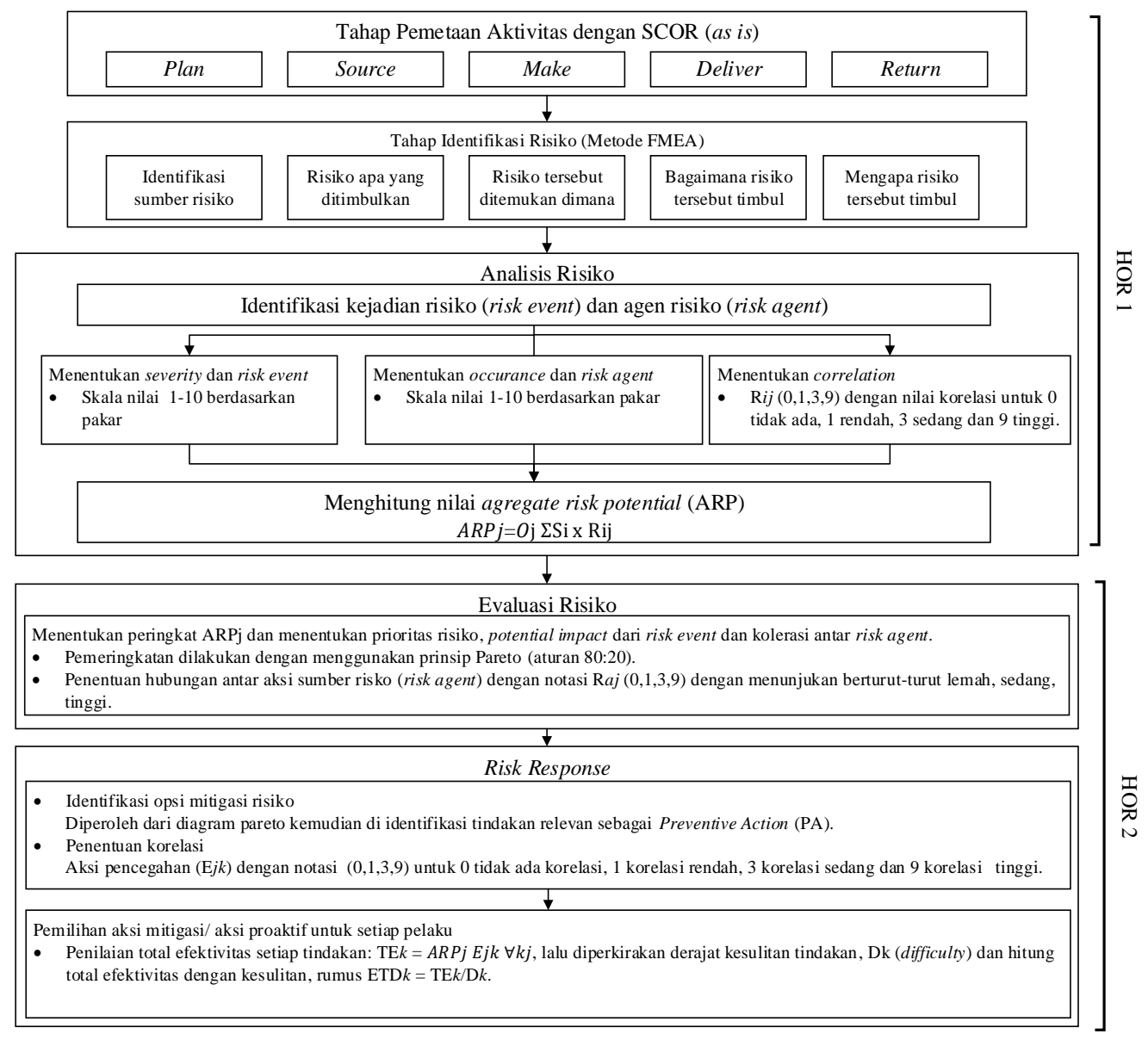

Gambar 2. Diagram alir metode HOR 


\section{HASIL DAN PEMBAHASAN}

\section{Struktur Jaringan dan Proses Bisnis Rantai Pasok Agroindustri Bawang Merah}

Rantai pasok agroindustri bawang merah melibatkan anggota yang mempunyai fungsi berbeda. Anggota rantai pasok yang terlibat mencakup petani sebagai pemasok dan produsen, pedagang pengumpul sebagai distributor, serta industri bawang goreng yang berperan dalam pengolahan produk. Terdapat dua pengumpul dalam penelitian ini, pengumpul 1 berperan sebagai pedagang mengumpulkan langsung dari petani dan pengumpul 2 merupakan pedagang yang mengumpulkan dari pedagang pengumpul lain yang nantinya didistribusikan untuk memenuhi kebutuhan industri bawang merah.Dalammeningkatkan kinerja rantai pasok untuk menjadi efisien dan responsif diperlukan penjelasan driver logistik dan lintas fungsional yang mencakup fasilitas, inventory, transportasi, informasi, sumberdaya dan harga (Chopra dan Meindl, 2013).

Pola aliran yang dijelaskan mencakup aliran produk, informasi dan keuangan dalam rantai pasok. Selain itu terdapat aliran yang ditinjau dari proses push-pull. Tinjauan berdasarkan proses push-pull mengkategorikan proses rantai pasok berdasarkan pada tanggapan terhadap pesanan konsumen (pull) atau antisipasi pesanan konsumen (push) (Chopra dan Meindl, 2013). Strategi push-pull akan berguna untuk mempertimbangkan strategi keputusan terkait desain rantai pasok dalam mencapai keberlanjutan. Terdapat dua proses push-pull yang berbeda pada rantai pasok agroindustri bawang merah dalam penelitian ini. Proses produksi pada agroindustri bawang merah di Brebes dilakukan berdasarkan permintaan dari konsumen. Sedangkan pada agroindustri di Kuningan dilakukan berdasarkan penyimpanan produk untuk mengantisipasi permintaan konsumen. Pada agroindustri bawang merah di Kuningan harga relatif lebih stabil dibandingkan dengan harga agroindustri bawang merah yang di Brebes. Secara umum, hasil analisis pola aliran dan siklu spush-pull rantai pasok agroindustri bawang merah dapat dilihat pada Gambar 3.

\section{Pengukuran Kinerja Rantai Pasok \\ Pembobotan Metrik Kinerja Rantai Pasok}

Hasil pembobotan matriks kinerja menunjukan bahwa budidaya merupakan proses bisnis yang paling penting dibandingkan dengan proses bisnis lainnya. Proses budidaya penting karena keseluruhan proses rantai pasok akan berjalan baik jika bahan baku yang dihasilkan dalam proses budidaya tersedia sesuai dengan permintaan. Hasil pembobotan parameter kinerja diperoleh nilai tambah 0,311, mitigasi risiko 0,449, dan produktivitas 0,240. Risiko dalam rantai pasok menyebabkan keberlanjutan rantai pasok terganggu. Berdasarkan hasil pendapat pakar mitigasi risiko merupakan tindakan yang paling penting dalam aktivitas rantai pasok agroindustri bawang merah. Mitigasi risiko perlu dilakukan untuk pencegahan dan penanganan risikoyang memiliki potensi besar menimbulkan kerugian dalam rantai pasok.

Hasil pembobotan pada level atribut kinerja, reliabilitas memiliki nilai tertinggi yaitu sebesar 0,342 , mengindikasikan bahwa kemampuan rantai pasok dalam memenuhi permintaan konsumen sesuai keinginannya sangat penting sehingga meningkatkan kepercayaan konsumen. Menurut So dan Sculli (2002) kepercayaan dibangun melalui tindakan yang konsisten dan dapat memprediksi tindakan bagi pelaku rantai pasok untuk perencanaan jangka panjang. Selain itu reliabilitas memiliki peranan yang penting dalam memenuhi fungsi rantai pasok yang responsif dan tangkas (Svensson, 2001).
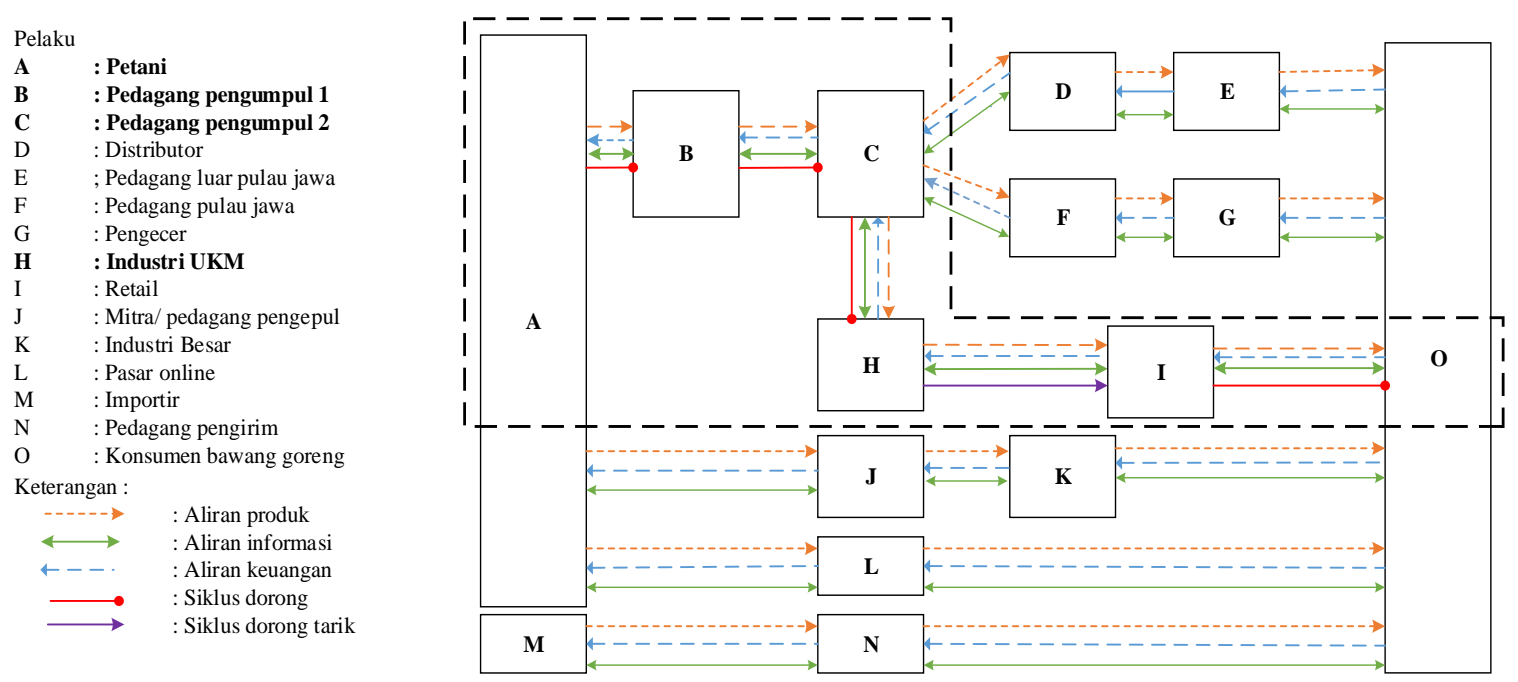

Gambar 3. Pola aliran dan siklus rantai pasok agroindustri bawang merah 
Pada hasil pembobotan metrik kinerja, diketahui hasil pembobotan siklus pemenuhan yaitu waktu yang dibutuhkan untuk pemenuhan pesanan mempunyai nilai tertinggi yaitu sebesar 0,216 dan diikuti oleh kemampuan perusahaan dalam melakukan pemenuhan pesanan untuk konsumen 0,159 ; biaya pengolahan 0,153 ; penyesuaian rantai pasok atas 0,107; kesesuaian standar mutu 0,103; biaya perawatan 0,099; kinerja pengiriman 0,080;fleksibilitas rantai pasok atas 0,052 dan penyesuaian rantai pasok bawah 0,029. Hasil pembobotan struktur SCOR-AHP dari pakar yang disintesis dengan menggunakan bantuan software Expert Choice 11 tertera dalam Gambar 4.

\section{Hasil Pengukuran Kinerja Rantai Pasok}

Penilaian kinerja rantai pasok dilakukan melalui perbandingan berpasangan sehingga menghasilkan bobot hasil pendapat pakar, untuk memperoleh nilai metrik kinerja maka dilakukan benchmarking data aktual terhadap pesaing yang relevan pada setiap tingkat pelaku dari petani, pengumpul sampai agroindustri bawang merah. Hasil penilaian kinerja anggota rantai pasok agroindustri bawang merah yang dilakukan pada setiap tingkat pelaku secara rincian tertera pada Tabel 1.

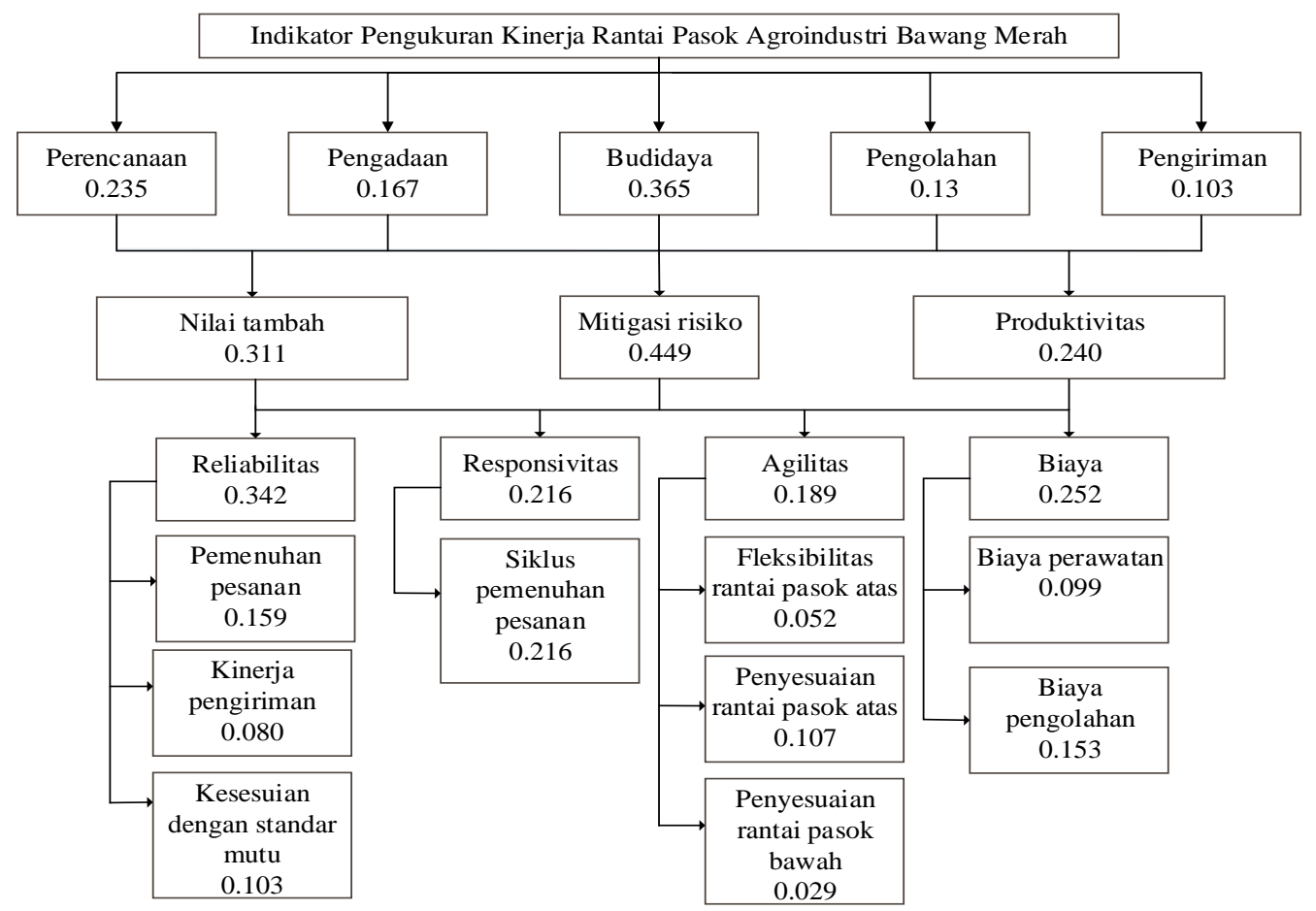

Gambar 4. Hirarki dan hasil pembobotan metrik pengukuran kinerja rantai pasok agroindustri bawang merah

Tabel 1 Nilai kinerja rantai pasok agroindustri bawang merah

\begin{tabular}{|c|c|c|c|c|c|}
\hline \multirow{2}{*}{$\begin{array}{l}\text { Atribut } \\
\text { Kinerja }\end{array}$} & \multirow{2}{*}{ Metrik Kinerja } & \multicolumn{4}{|c|}{ \% Nilai Matriks Kinerja } \\
\hline & & Petani & Pengumpul1 & Pengumpul2 & Industri \\
\hline \multirow[t]{3}{*}{ Reliabilitas } & Pemenuhan pesanan & 18,68 & 12,10 & 24,20 & 16,40 \\
\hline & Kinerja pengiriman & 9,36 & 6,06 & 12,13 & 8,22 \\
\hline & Kondisi sempurna & 12,13 & 8,64 & 7,86 & 10,65 \\
\hline \multirow{4}{*}{$\begin{array}{l}\text { Responsivitas } \\
\text { Agilitas }\end{array}$} & Siklus pemenuhan pesanan & 32,91 & 32,91 & 32,91 & 7,43 \\
\hline & $\begin{array}{l}\text { Fleksibilitas rantai pasokan } \\
\text { atas }\end{array}$ & - & - & - & 5,41 \\
\hline & $\begin{array}{l}\text { Penyesuaian rantai pasokan } \\
\text { atas }\end{array}$ & - & - & - & 10,32 \\
\hline & $\begin{array}{l}\text { Penyesuaian rantai pasokan } \\
\text { bawah }\end{array}$ & - & - & - & - \\
\hline \multirow[t]{2}{*}{ Biaya } & Biaya perawatan & 2,30 & 14,71 & 14,87 & 8,05 \\
\hline & Biaya pengolahan & & & & 8,30 \\
\hline Total & & 75,38 & 74,43 & 91,97 & 74,79 \\
\hline
\end{tabular}


Nilai atribut agilitas di tingkat petani dan pengumpul tidak dapat dihitung sehingga dilakukan normalisasi bobot. Berdasarkan hasil perhitungan terhadap nilai kinerja, diketahui bahwa kinerja rantai pasok di tingkat petani sebesar $75,38 \%$, pengumpul1 sebesar $74,43 \%$ dan industri sebesar $74,79 \%$ masuk dalam klasifikasi kinerja kurang baik (below average) (Monczka et al., 2011). Nilai kinerja di tingkat pengumpul2 sebesar 91,97\% masuk dalam klasifikasi kinerja baik (above average). Kinerja petani bawang merah yang kurang baik dikarenakan faktor ketidakpastian musim yang mengakibatkan munculnya masalah dalam proses budidaya berupa hama penyakit yang sulit diatasi sehingga menyebabkan penurunan produksi hingga kegagalan panen. Di tingkat industri kinerja masih tergolong kurang baik karena proses produksi bergantung pada harga bahan baku, kondisi harga yang berfluktuatif sering menghambat proses produksi. Di tingkat pengumpul kinerja yang kurang baik dikarenakan tingkat pemenuhan pesanan dan kinerja pengiriman yang masih rendah sehingga proses pemenuhan pesanan sering kali terhambat.

\section{Analisis Nilai Tambah}

Perhitungan nilai tambah dilakukan untuk mengetahui besaran rasio nilai tambah dan keuntungan setiap pelaku yang terlibat dalam rantai pasok. Input yang digunakan dalam analisis nilai tambah pada setiap pelaku terdiri atas jumlah output, bahan baku, tenaga kerja, harga output, upah tenaga kerja, harga bahan baku dan harga input lainnya. Hasil perhitungan nilai tambah setiap pelaku secara rinci tertera dalam Tabel 2.

Berdasarkan hasil perhitungan nilai tambah, diketahui bahwa rasio nilai tambah tertinggi berturut-turut disetiap tingkat pelaku yaitu industri $53,75 \%$, petani $46,06 \%$, pengumpul $18,88 \%$ dan pengumpul $25,39 \%$. Rendahnya rasio nilai tambah di tingkat pengumpul dikarenakan tidak adanya perubahan nilai yang signifikan yang dilakukan karena proses yang terjadi hanya sortasi dan grading. Hasil analisis margin keuntungan setiap pelaku, petani mempunyai nilai terendah jika dibandingkan dengan pelaku lainnya yaitu sebesar 76,91\%. Industri bawang merah memiliki rasio keuntungan paling tinggi yaitu sebesar $82,02 \%$. Tingkat keuntungan yang tinggi karena terdapat proses transformasi bahan baku menjadi produk sehingga meningkatkan nilai jual dan nilai tambah bawang merah.

Tabel 2. Hasil perhitungan nilai tambah setiap pelaku

\begin{tabular}{|c|c|c|c|c|c|}
\hline No & Variabel & Petani & Pengumpul1 & Pengumpul 2 & Industri \\
\hline \multicolumn{6}{|c|}{ Output, Input, dan Harga } \\
\hline 1 & Output (kg/periode) & 3.750 & 188.000 & 375.000 & 1.120 \\
\hline 2 & Bahan baku (kg/periode) & 837,5 & 200.000 & 375.000 & 3.200 \\
\hline 3 & Tenaga kerja langsung (hari/periode) & 50 & 50 & 50 & 50 \\
\hline 4 & Faktor konversi & 4,48 & 0,940 & 1 & 0,35 \\
\hline 5 & $\begin{array}{l}\text { Koefisien tenaga kerja langsung } \\
(\mathrm{HOK} / \mathrm{kg})\end{array}$ & $6 \times 10^{-2}$ & $3 \times 10^{-4}$ & $1.3 \times 10^{-4}$ & $1.5 \times 10^{-2}$ \\
\hline 6 & Harga output $(\mathrm{Rp} / \mathrm{kg})$ & 17.750 & 18.000 & 19.000 & 150.000 \\
\hline 7 & Upah tenaga kerja langsung (Rp/hari) & 56.250 & 72.500 & 90.833 & 100.000 \\
\hline \multicolumn{6}{|c|}{ Penerimaan dan Keuntungan } \\
\hline 8 & Harga bahan baku (Rp/kg) & 36.250 & 15.000 & 17.750 & 20.000 \\
\hline 9 & Harga input lain $(\mathrm{Rp} / \mathrm{kg})$ & 6.600 & 400 & 230 & 4.300 \\
\hline 10 & Nilai output $(\mathrm{Rp} / \mathrm{kg})$ & 79.500 & 16.900 & 19.000 & 52.500 \\
\hline \multirow[t]{2}{*}{11} & a. Nilai tambah $(\mathrm{Rp} / \mathrm{kg})$ & 36.600 & 1.500 & 1.000 & 28.200 \\
\hline & b. Rasio nilai tambah (\%) & 46,06 & 8,88 & 5,39 & 53,75 \\
\hline \multirow[t]{2}{*}{12} & $\begin{array}{l}\text { a. Pendapatan tenaga kerja langsung } \\
(\mathrm{Rp} / \mathrm{kg})\end{array}$ & 3.400 & 18,13 & 12,11 & 1.700 \\
\hline & b. Pangsa tenaga kerja langsung (\%) & 9,17 & 1,21 & 1,18 & 5,54 \\
\hline \multirow[t]{2}{*}{13} & a. Keuntungan $(\mathrm{Rp} / \mathrm{kg})$ & 33.300 & 1.500 & 1.000 & 26.700 \\
\hline & b. Tingkat keuntungan $(\%)$ & 41,83 & 8,78 & 5,33 & 50,77 \\
\hline \multicolumn{6}{|c|}{ Balas Jasa Pemilik Faktor Produksi } \\
\hline \multirow[t]{4}{*}{14} & Margin (Rp/kg) & 43.200 & 1.900 & 1.250 & 32.500 \\
\hline & $\begin{array}{l}\text { a. Pendapatan tenaga kerja langsung } \\
(\%)\end{array}$ & 7,76 & 0,94 & 0,97 & 4,81 \\
\hline & b. Sumbangan input lain $(\%)$ & 15,31 & 21,70 & 18,07 & 13,17 \\
\hline & c. Keuntungan perusahaan $(\%)$ & 76,91 & 77,35 & 80,96 & 82,02 \\
\hline
\end{tabular}




\section{Analisis Risiko Rantai Pasok Agroindustri Bawang Merah}

Untuk menilai dampak risiko rantai pasok, suatu perusahaan harus mengidentifikasi tidak hanya risiko langsung terhadap operasinya tetapi juga penyebab potensial atau sumber risiko tersebut pada setiap hubungan sepanjang rantai pasok (Christopher et al., 2002). Hasil identifikasi yang dilakukan baik dari lapang, literatur maupun pakar diperoleh sumber dan kejadian risiko padasetiap pelaku berturut-turut petani sebanyak 36 dan 8 , industri sebanyak 19 dan 8, dan pengumpul sebanyak 20 dan 7. Dari keseluruhan nilai ARP pada sumber risiko dilakukan pemilihan prioritas sumber risiko berdasarkan aturan pareto (80:20). Hasil penilaian ARP (agregate risk potential) yang terpilih dijadikan sumber risiko prioritas untuk diberikan tindakan pencegahan berdasarkan pendapat pakar. Sumber risiko prioritas yang perlu diberikan aksi pencegahan pada setiap pelaku sebanyak 21 untuk petani, 14 untuk pengumpul, dan 11 untuk industri. Hasil perhitungan $\mathrm{ARP}_{j}$ pada sumber risiko prioritas pada setiap pelaku tertera dalam Tabel 3.

Hasil analisis perhitungan nilai ARP setiap sumber resiko di tingkat petani diketahui bahwa sumber risiko yang memiliki nilai ARP tertinggi seperti sulitnya mendapatkan air ketika musim kemarau, modal usaha tani bawang merah tinggi dan terjadi kegagalan panen karena perencanaan yang kurang tepat. Nilai tersebut diperoleh berdasarkan pendapat pakar melalui penilaian tingkat keparahan risiko dan kemungkinan terjadinya risiko pada petani. Petani dalam penanaman bawang merah mempertimbangkan ketersediaan air dalam penanamannya karena bawang merah membutuhkan banyak air (Aldila et al., 2015). Bawang merah jika kekurangan air umbi yang dihasilkan berukuran kecil sehingga mengurangi keuntungan petani. Selain itu musim kemarau meningkatkan biaya produksi akibat penggunaan bahan bakar untuk pompa air. Risiko adanya hama dan penyakit yang sulit ditanggulangi menyebabkan penggunaan pupuk dan pestisida dilakukan secara berlebihan sehingga meningkatkan modal usahatani bawang merah.

Di tingkat pengumpul sumber risiko yang memiliki nilai ARP tertinggi seperti bawang merah susut karena musim hujan, kerusakan bawang merah akibat ketidakpastian cuaca dan harga tidak sesuai dengan keinginan. Pemasalahan dalam usaha tani bawang merah di musim hujan menurut petani adalah masalah kerusakan tanaman akibat serangan penyakit, kabut, hama dan hujan (Basuki, 2014). Produktivitas dan kualitas bawang yang rendah menyebabkan keuntungan yang diperoleh baik oleh petani maupun pengumpul turut rendah. Hasil perhitungan $\mathrm{ARP}_{j}$ pada sumber risiko prioritas pada setiap pelaku tertera dalam Tabel 4 .

Di tingkat industri sumber risiko yang memiliki nilai ARP tertinggi seperti kemampuan supplier memenuhi permintaan rendah, kekurangan kapasitas pasokan material dan kemampuan supplier memenuhi permintaan sesuai jadwal rendah. Risikorisiko tersebut muncul dikarenakan terjadinya fluktuasi produksi akibat karakteristik bawang merah di setiap musim yang berbeda sehingga produksi tidak kontinyu dan menghambat pasokan bawang merah. sumber risiko prioritas di tingkat industri tertera dalam Tabel 5.

Tabel 3. Hasil perhitungan $\mathrm{ARP}_{j}$ di tingkat petani

\begin{tabular}{|c|c|c|c|}
\hline Rank & Kode & Sumber Risiko & ARP \\
\hline 1 & A13 & Sulit mendapatkan air ketika musim kemarau & 2.066 \\
\hline 2 & $\mathrm{~A} 2$ & Modal usaha tani bawang merah tinggi & 1.778 \\
\hline 3 & A1 & Terjadi kegagalan panen akibat perencanaan kurang tepat & 1.740 \\
\hline 4 & A22 & Penurunan produksi dan kualitas bawang merah akibat penurunan produktivitas lahan & 1.223 \\
\hline 5 & $\mathrm{~A} 23$ & Penambahan biaya usaha tani karena produktivitas lahan menurun & 1.215 \\
\hline 6 & A21 & Fluktuasi harga jual & 1.092 \\
\hline 7 & A11 & Hasil panen tidak maksimal & 1.053 \\
\hline 8 & A19 & Harga jual rendah & 969 \\
\hline 9 & $\mathrm{~A} 27$ & Tingkat produktivitas dan kualitas rendah akibat ketidakpastian musim & 936 \\
\hline 10 & A 35 & Ketidaksesuaian ukuran hasil & 871 \\
\hline 11 & A33 & Bawang tercecer saat pengangkutan & 842 \\
\hline 12 & A24 & Umbi yang dihasilkan kecil & 780 \\
\hline 13 & A9 & Pengadaan bibit kurang baik & 744 \\
\hline 14 & A18 & Posisi tawar petani rendah & 672 \\
\hline 15 & A 28 & Peningkatan biaya produksi akibat pupuk dan pestisida akibat ketidakpastian musim & 664 \\
\hline 16 & A4 & Salah memilih lokasi tanam & 650 \\
\hline 17 & A 20 & Pembayaran rendah karena sistem tebas & 638 \\
\hline 18 & A29 & Biaya transportasi tinggi & 585 \\
\hline 19 & A14 & Terkena banjir ketika musim hujan & 558 \\
\hline 20 & A26 & Terserang hama dan penyakit tanaman & 536 \\
\hline 21 & $\mathrm{~A} 25$ & Gagal panen akibat produktivitas lahan menurun & 528 \\
\hline
\end{tabular}


Tabel 4. Hasil $\mathrm{ARP}_{j}$ di tingkat pengumpul

\begin{tabular}{cclr}
\hline Rank & Kode & \multicolumn{1}{c}{ Sumber Risiko } & ARP \\
\hline 1 & A9 & Bawang merah susut karena musim hujan & 1.288 \\
2 & A19 & Kerusakan bawang merah akibat ketidakpastian cuaca & 1.145 \\
3 & A1 & Harga tidak sesuai keinginan & 1.000 \\
4 & A3 & Harga bawang merah menurun ketika impor akibat fluktuasi harga & 644 \\
5 & A11 & Jumlah pasokan tidak terpenuhi kerusakan saat perjalanan & 624 \\
6 & A10 & Penurunan kualitas & 605 \\
7 & A5 & Jumlah kuota tidak memenuhi permintaan & 604 \\
8 & A2 & Kualitas bawang merah tidak sesuai karena fluktuasi harga & 556 \\
9 & A6 & Kualitas bawang merah tidak sesuai karena musim hujan & 544 \\
10 & A7 & Kerusakan bawang merah akibat kesalahan pengemasan & 520 \\
11 & A13 & Biaya transportasi mahal & 519 \\
12 & A20 & Bawang merah susut dan busuk & 511 \\
13 & A14 & Kekurangan tenaga kerja & 510 \\
14 & A4 & Kekurangan modal untuk membeli kembali & 508 \\
\hline
\end{tabular}

Tabel 5. Hasil $\mathrm{ARP}_{j}$ di tingkat industri

\begin{tabular}{cclr}
\hline Rank & Kode & \multicolumn{1}{c}{ Sumber Risiko } & ARP \\
\hline 1 & A7 & Kemampuan supplier memenuhi permintaan rendah & 1.242 \\
2 & A13 & Kekurangan kapasitas pasokan material & 1.161 \\
3 & A4 & Kemampuan supplier memenuhi permintaan sesuai jadwal rendah & 1.035 \\
4 & A1 & Keterlambatan pasokan karena perubahan rencana produksi & 786 \\
5 & A15 & Penyelesaian produk tidak sesuai jadwal & 720 \\
6 & A6 & Pengadaan material terlambat akibat ketidaksesuaian material yang dipesan & 558 \\
7 & A5 & Permintaan produk mendadak karena ketidaksesuaian jumlah kapasitas & 533 \\
8 & A14 & Kesalahan informasi & 518 \\
9 & A16 & Kekurangan jumlah transportasi & 426 \\
10 & A2 & Permintaan produk mendadak akibat perubahan rencana produksi & 423 \\
11 & A10 & Kesalahan dalam memasukan input & 405 \\
\hline
\end{tabular}

Berdasarkan hasil perhitungan nilai ARP pada sumber risiko prioritas maka disusun aksi mitigasi berdasarkan pendapat pakar untuk mengurangi sumber risiko pada setiap pelaku rantai pasok. Penilaian terhadap tindakan penanganan risiko dilakukan dengan mempertimbangkan tingkat kesulitan $\left(\boldsymbol{D}_{\boldsymbol{k}}\right)$ berdasarkan efisiensi biaya dan tindakan paling layak. Pemilihan aksi mitigasi prioritas setiap pelaku dilakukan dengan menggunakan aturan pareto (80:20). Hasil analisis pada tahapan HOR 2 diperoleh aksi mitigasi risiko prioritas yang dapat diterapkan setiap pelaku rantai pasok yaitu 14 untuk petani, 9 untuk pengumpul, dan 8 untuk industri.

Aksi mitigasi terbaik di tingkat pengumpul dengan PA3 digunakan untuk menanggulangi sumber risiko prioritas dengan kerusakan bawang merah akibat ketidakpastian cuaca (A19). PA11 digunakan untuk menanggulangi terjadinya penurunan kualitas (A10). PA14 digunakan untuk menanggulangi sumber risiko prioritas jumlah pasokan tidak terpenuhi karena kerusakan saat perjalanan (A14). Aksi mitigasi yang terpilih untuk pencegahan sumber risiko prioritas di tingkat pengumpul secara rinci tertera dalam Tabel 6 .

Aksi mitigasi terbaik di tingkat industri dengan PA1 digunakan untuk menanggulangi sumber risiko prioritas yaitu kemampuan supplier memuhi permintaan rendah (A7). PA2 digunakan untuk menanggulangi sumber risiko terjadinya kekurangan kapasitas pasokan material (A13). PA3 digunakan untuk menanggulangi kemampuan supplier memenuhi permintaan sesuai jadwal rendah (A4). Aksi mitigasi yang terpilih untuk pencegahan sumber risiko prioritas di tingkat industri secara rinci tertera dalam Tabel 7.

Hasil pemilihan aksi mitigasi diperoleh tiga terbaik di tingkat petani, PA15 digunakan untuk menanggulangi sumber risiko prioritas yaitu peningkatan biaya produksi akibat pupuk dan pestisida akibat ketidakpastian musim (A28). PA6 digunakan untuk menanggulangi sumber risiko yaitu adanya fluktuasi harga jual (A21). PA5 digunakan untuk menanggulangi sumber risiko prioritas adanya penambahan biaya usaha tani karena produktivitas lahan menurun (A23).Aksi mitigasi yang terpilih untuk pencegahan sumber risiko prioritas di tingkat petani secara rinci tertera dalam Tabel 8 . 
Tabel 6. Prioritas aksi mitigasi di tingkat pengumpul

\begin{tabular}{|c|c|c|c|c|c|}
\hline Rank & Kode & Aksi Preventif (PA) & $D_{k}$ & $T E_{k}$ & $\begin{array}{l}\text { Nilai } \\
\text { ETD }\end{array}$ \\
\hline 1 & PA3 & $\begin{array}{l}\text { Perbaikan SOP pascapanen dari mulai penggudangan, memilih } \\
\text { tenaga terampil dan sarana penjemuran }\end{array}$ & 7 & 25.739 & 3.677 \\
\hline 2 & PA11 & $\begin{array}{l}\text { Perbaikan SOP budidaya dan pascapanen serta membeli bawang } \\
\text { merah dengan kualitas yang baik }\end{array}$ & 7 & 24.673 & 3.525 \\
\hline 3 & PA14 & $\begin{array}{l}\text { Perbaikan aplikasi SOP pascapanen dengan penyediaan gudang, } \\
\text { lantai jemur, tenaga prosessing yang terampil }\end{array}$ & 8 & 27.311 & 3.414 \\
\hline 4 & PA1 & $\begin{array}{l}\text { Melakukan kemitraan dan mengembangkan jaringan pemasaran } \\
\text { didaerah lain }\end{array}$ & 7 & 19.427 & 2.904 \\
\hline 5 & PA2 & $\begin{array}{l}\text { Perbaikan SOP pascapanen dan pembelian mesin pengering atau } \\
\text { penerapan teknologi penyimpanan dingin }\end{array}$ & 6 & 17.425 & 2.836 \\
\hline 6 & PA4 & Melakukan kemitraan dengan penebas dan pedagang lain. & 6 & 14.885 & 2.775 \\
\hline 7 & PA6 & $\begin{array}{l}\text { Melakukan manajemen transportasi kolaboratif dan } \\
\text { pengembangan ekspedisi pengiriman sendiri }\end{array}$ & 7 & 19.855 & 2.481 \\
\hline 8 & PA13 & $\begin{array}{l}\text { Memiliki gudang penyimpanan dan serta melakukan } \\
\text { pengembangan jaringan pemasaran. }\end{array}$ & 6 & 11.255 & 2.009 \\
\hline 9 & PA5 & $\begin{array}{l}\text { Melakukan manajemen transportasi kolaboratif dan } \\
\text { pengembangan ekspedisi pengiriman sendiri }\end{array}$ & 7 & 14.060 & 1.876 \\
\hline
\end{tabular}

Tabel 7. Prioritas aksi mitigasi di tingkat industri

\begin{tabular}{|c|c|c|c|c|c|}
\hline Rank & Kode & Aksi Preventif (PA) & $D_{k}$ & $T E_{k}$ & $\begin{array}{l}\text { Nilai } \\
\text { ETD }\end{array}$ \\
\hline 1 & PA1 & $\begin{array}{l}\text { Peningkatan kapasitas supplier dengan melakukan pemeriksaan } \\
\text { secara berkala terhadap supplier }\end{array}$ & 8 & 23.473 & 2.934 \\
\hline 2 & PA2 & $\begin{array}{l}\text { Kontrak kerja dengan petani atau kelompok tani serta } \\
\text { pengontrolan persediaan }\end{array}$ & 8 & 22.987 & 2.873 \\
\hline 3 & PA3 & $\begin{array}{l}\text { Pemberlakuan penalti atas keterlambatan dan penetapan } \\
\text { portofolio supplier utama }\end{array}$ & 8 & 19.543 & 2.443 \\
\hline 4 & PA7 & $\begin{array}{l}\text { Negosiasi jadwal pemenuhan permintaan dan kontrol } \\
\text { ketersediaan }\end{array}$ & 8 & 19.215 & 2.402 \\
\hline 5 & PA5 & $\begin{array}{l}\text { Perbaikan sistem penjadwalan finalisasi produk akhir dan } \\
\text { melakukan manajemen penggudangan }\end{array}$ & 6 & 12.610 .5 & 2.102 \\
\hline 6 & PA4 & Melakukan perencanaan pasokan dengan baik dan benar & 7 & 13.528 & 1.933 \\
\hline 7 & PA10 & $\begin{array}{l}\text { Negoisasi jadwal pemenuhan permintaan dan kontrol } \\
\text { ketersediaan }\end{array}$ & 7 & 11.484 & 1.641 \\
\hline 8 & PA6 & $\begin{array}{l}\text { Pemberlakuan penalti atas keterlambatan dan perencanaan } \\
\text { permintaan dengan memperhatikan keterlambatan pengiriman }\end{array}$ & 8 & 11.440 & 1.430 \\
\hline
\end{tabular}

Tabel 8 Prioritas aksi mitigasi di tingkat petani

\begin{tabular}{|c|c|c|c|c|c|}
\hline Rank & Kode & Aksi Preventif (PA) & $D_{k}$ & $T E_{k}$ & Nilai ETD \\
\hline 1 & PA15 & Melakukan optimalisasi saprodi & 6.5 & 98.690 & 15.183 \\
\hline 2 & PA6 & $\begin{array}{l}\text { Aplikasi SOP budidaya dan pengembangan sistem } \\
\text { kolektif }\end{array}$ & 6.5 & 96.041 & 14.775 \\
\hline 3 & PA5 & $\begin{array}{l}\text { Optimalisasi saprodi dan aplikasi SOP budidaya yang } \\
\text { benar }\end{array}$ & 8 & 106.188 & 13.274 \\
\hline 4 & PA9 & $\begin{array}{l}\text { Optimalisasi saprodi dan penerapan SOP budidaya yang } \\
\text { benar }\end{array}$ & 8 & 105.444 & 13.181 \\
\hline 5 & PA4 & Penerapan dan aplikasi SOP budidaya dan panen & 8 & 102.162 & 12.770 \\
\hline 6 & PA12 & Aplikasi SOP Budidaya yang benar & 8 & 101.198 & 12.650 \\
\hline 7 & PA7 & Penerapan dan aplikasi SOP Budidaya dan panen & 8 & 100.803 & 12.600 \\
\hline 8 & PA20 & Peningkatan kapasitas petani dalam manajemen PHT & 7.5 & 71.169 & 9.489 \\
\hline 9 & PA21 & $\begin{array}{l}\text { Pengembangan sistem kolektif untuk produksi, } \\
\text { pascapanen dan pemasaran }\end{array}$ & 6.5 & 61.478 & 9.458 \\
\hline 10 & PA10 & Aplikasi SOP budidaya dan pascapanen yang benar & 8 & 75.008 & 9.376 \\
\hline 11 & PA1 & Pembuatan embung dan sumur patek & 4.5 & 41.505 & 9.223 \\
\hline 12 & PA14 & $\begin{array}{l}\text { Pengembangan sistem penyimpanan dan SOP } \\
\text { penyimpanan }\end{array}$ & 7 & 46.128 & 6.590 \\
\hline 13 & PA11 & $\begin{array}{l}\text { Menerapkan manajemen pascapanen dan logistik yang } \\
\text { tepat }\end{array}$ & 7.5 & 48.227 & 6.430 \\
\hline 14 & PA3 & Pengembangan budidaya multi lokasi & 7 & 44.373 & 6.339 \\
\hline
\end{tabular}


Pemilihan Strategi Peningkatan Kinerja, Nilai Tambah dan Mitigasi Risiko

Strategi peningkatan pada rantai pasok agroindustri bawang merah secara berkelanjutan dilakukan berdasarkan indikator analisis benefit, opportunity, cost, dan risk (BOCR) untuk memilih alternatif pada struktur ANP, pemilihan prioritas dari alternatif diperoleh dari benefit-cost ratio dengan membandingkan antara bobot yang memiliki pengaruh positif terhadap bobot pengaruh negatif, alternatif terpilih merupakan hasil rasio nilai terbesar (Saaty, 2005).

Struktur jaringan ANP-BOCR untuk pemilihan strategi peningkatan kinerja, nilai tambah dan mitigasi risiko terdiri atas kriteria utama, kriteria, subkriteria dan alternatif strategi. Penentuan alternatif terpilih berdasarkan pada elemen BOCR (benefit, opportunity, cost, dan risk) yang masingmasing didekomposisi menjadi empat elemen kriteria yaitu sosial, ekonomi, lingkungan dan teknologi.

Elemen benefit, kriteria sosial memiliki subkriteria peningkatan jaringan bisnis (PJB) dan peningkatan permintaan (PP). Kriteria ekonomi memiliki subkriteria peningkatan kualitas produk (PKP), peningkatan keuntungan (PK) dan peningkatan produksi (PPr). Kriteria lingkungan memiliki subkriteria pengurangan penggunaan pestisida dan bahan kimia (PPK) dan peningkatan kualitas lahan (PKL). Pada kriteria teknologi memiliki subkriteria pengembangan teknologi produksi (PTP) dan pengembangan teknologi pengolahan (PTPo).

Elemen opportunity, kriteria sosial memiliki subkriteria peningkatan jumlah tenaga kerja (PTK), peningkatan kesejahteraan petani (PKPe) dan peningkatan pengetahuan petani (PPP). Kriteria ekonomi memiliki subkriteria peningkatan mutu bahan baku dan produk (PM), peningkatan ketersediaan bahan baku (PKB) dan peningkatan produktivitas hasil (PPH). Kriteria lingkungan memiliki subkriteria peningkatan pertanian ramah lingkungan (PPRL), serta kriteria teknologi memiliki subkriteria peningkatan sarana dan fasilitas (PSF).

Elemen cost, kriteria sosial memiliki subkriteria baiya peningkatan kapasitas stakeholder (BPKS). Kriteria ekonomi memiliki subkriteria biaya produksi (BP), biaya transportasi (BT) dan biaya inovasi produk (BIP). Kriteria lingkungan memiliki subkriteria biaya perbaikan lingkungan (BPL), serta kriteria teknologi memiliki subkriteria biaya perlatan dan teknologi (BPT).
Elemen risk, kriteria sosial memiliki subkriteria keterbatasan sumber daya manusia (KSM). Kriteria ekonomi memiliki subkriteria fluktuasi bahan baku (FB), kekurangan pasokan bahan baku (KBB) dan mutu bahan baku yang rendah (MB). Kriteria lingkungan memiliki subkriteria ketidakpastian musim (KM), serta kriteria teknologi memiliki subkriteria keterbatasan fasilitas penyimpanan (KFP) dan ketidaksesuaian teknologi (KST).

Alternatif strategi diperoleh berdasarkan hasil pengukuran kinerja, analisis nilai tambah dan mitigasi risiko pada rantai pasok. Berdasarkan hasil evaluasi kinerja, nilai tambah dan risiko pada rantai pasok agroindustri bawang merah diperoleh empat rekomendasi alternatif strategi antara lain penerapan SOP budidaya dan pascapanen yang tepat (PSBP), pengembangan kerjasama kolaboratif antar stakeholder (PKKS), pengembangan inovasi teknologi pengolahan (PITO) dan pengembangan kapasitas sumber daya manusia (PKSM). Struktur jaringan ANP untuk pemilihan alternatif peningkatan kinerja, nilai tambah dan mitigasi risiko rantai pasok agroindustri bawang merah dapat dilihat dalam Gambar 5.

Tahap ini menghasilkan alternatif strategi terbaik berdasarkan analisis ANP-BOCR. Hasil analisis BOCR terhadap alternatif strategi peningkatan kinerja, nilai tambah dan mitigasi risiko rantai pasok berkelanjutan agroindustri bawang merah diperoleh bobot prioritas setiap alternatif strategi dalam subkriteria. Validasi dilakukan melalui pakar dengan menggunakan kuesioner. Verifikasi dilakukan dengan menggunakan Microsoft Excel untuk agregasi pendapat pakar dan software Super Decisions untuk analisis BO/CR. Hasil penilaian terhadap alternatif strategi tertera dalam Tabel 9. Hasil pemilihan alternatif strategi melalui ANP-BOCR diperoleh alternatif strategi terbaik berdasarkan nilai $B O / C R$ yaitu penerpan SOP budidaya dan pascapanen yang tepat. Alternatif tersebut menurut pendapat pakar merupakan alternatif terbaik yang dapat digunakan untuk meningkatkan kinerja, nilai tambah dan mitigasi risiko pada rantai pasok agroindustri bawang merah. Alternatif terpilih mempunyai nilai $B O / C R$ paling besar yaitu sebesar 0,547 dapat direkomendasikan karena merupakan alternatif paling ideal dari segi keuntungan dan kesempatan dalam rangka menciptakan rantai pasok agroindustri bawang merah yang berkelanjutan.

Tabel 9. Hasil prioritas pemilihan alternatif berdasarkan kriteria BOCR

\begin{tabular}{lrrrrrr}
\hline Kriteria & $\begin{array}{c}\text { Benefit } \\
(\mathbf{0 , 4 6 )}\end{array}$ & $\begin{array}{c}\text { Opportunity } \\
(\mathbf{0 , 2 0})\end{array}$ & $\begin{array}{c}\text { Cost } \\
(\mathbf{0 , 1 6})\end{array}$ & $\begin{array}{c}\text { Risk } \\
(\mathbf{0 , 1 9})\end{array}$ & $\boldsymbol{B O} / \boldsymbol{C R}$ & Rank \\
\hline PSBP & 0,32 & 0,21 & 0,14 & 0,18 & 0,547 & 1 \\
PKSM & 0,26 & 0,31 & 0,36 & 0,24 & 0,188 & 2 \\
PKKS & 0,29 & 0,38 & 0,36 & 0,45 & 0,136 & 3 \\
PITO & 0,13 & 0,09 & 0,14 & 0,13 & 0,128 & 4 \\
\hline Jumlah & 1,00 & 1,00 & 1,00 & 1,00 & 1,00 & \\
\hline
\end{tabular}




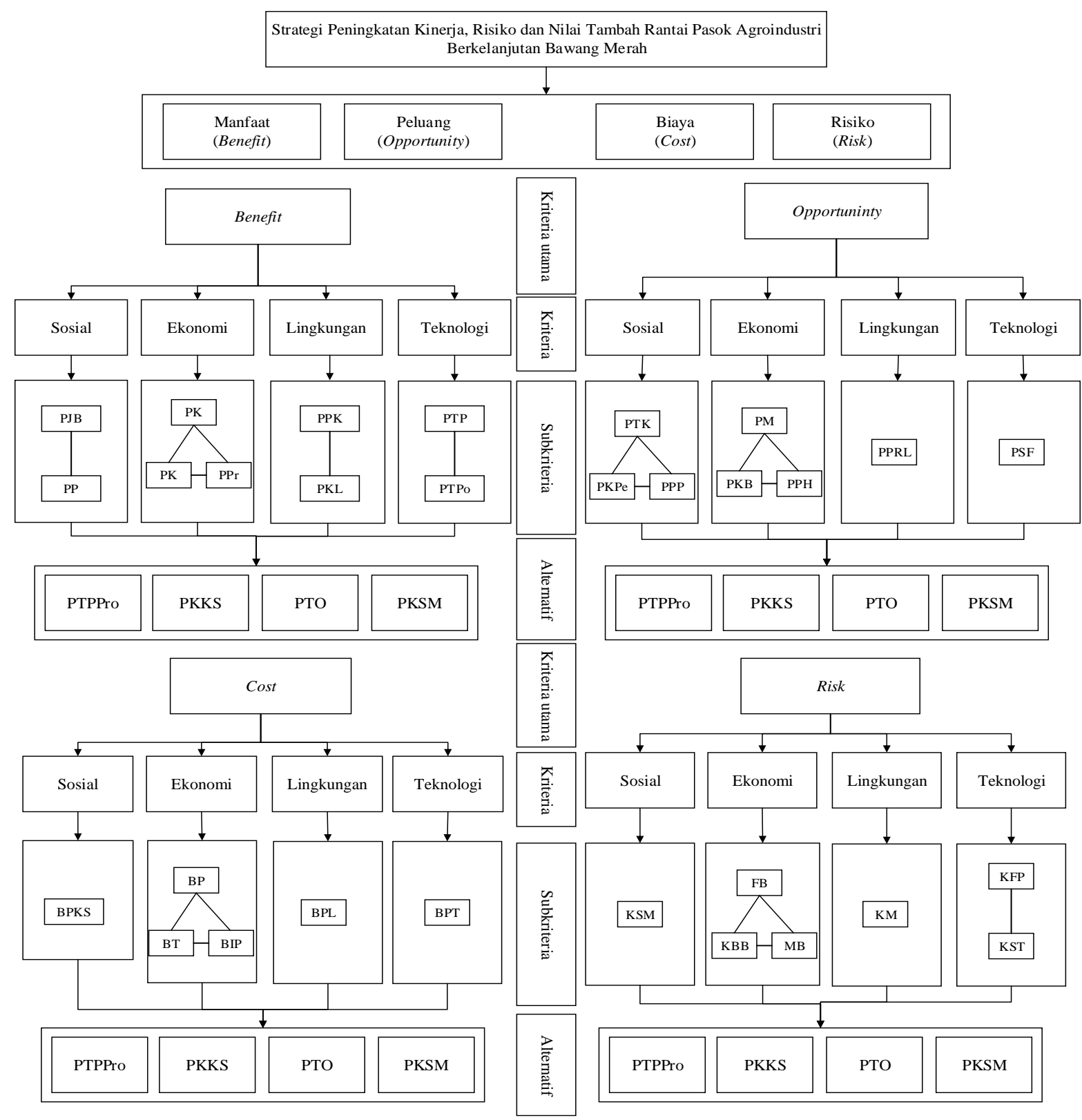

Gambar 5. Struktur jaringan ANP-BOCR rantai pasok agroindustri bawang merah

\section{Implikasi Manajerial}

Hasil pengamatan penelitian dan diskusi dengan pakar yang terlibat menunjukan bahwa titik kritis permasalahan dalam rantai pasok agroindustri bawang merah adalah kondisi kinerja yang masih kurang baik pada setiap pelaku dalam rantai pasok agroindustri bawang merah. Selain itu distribusi risiko dan nilai tambah yang tidak seimbang merupakan kondisi yang perlu ditangani. Evaluasi kinerja rantai pasok agroindustri bawang merah dilakukan untuk mengukur kinerja pada proses bisnis di setiap anggota rantai pasok. Pengukuran kinerja dengan pendekatan SCOR merupakan langkah yang tepat untuk mengetahui kondisi setiap proses bisnis dalam rantai pasok. Selain itu pendekatan SCOR memudahkan dalam memetakan risiko-risiko di setiap proses bisnis guna memperoleh strategi mitigasi terbaik penanganan sumber risiko. Pengukuran kinerja, analisis nilai tambah dan analisis risiko yang terintegrasi dari hulu ke hilir berguna dalam merancang strategi perbaikan rantai pasok untuk mencapai keberlanjutan.

Hasil analisis dan evaluasi risiko dalam rantai pasok memudahkan dalam memilihan keputusan untuk merancang aksi mitigasi yang terbaik pada setiap pelaku rantai pasok. Analisis aksi mitigasi setiap pelaku dapat digunakan sebagai pertimbangan oleh setiap pelaku rantai pasok untuk menyusun strategi perencanaan dari mulai budidaya sampai pengolahan. Hasil analisis aksi mitigasi juga dapat menjadi bahan pertimbangan bagi pemerintah dalam menyusun kebijakan strategi pengembangan rantai pasok agroindustri bawang merah kedepannya. 
Alternatif strategi yang dihasilkan untuk peningkatan kinerja, nilai tambah dan mitigasi risiko pada rantai pasok agroindustri bawang merah adalah penerapan SOP budidaya dan pascapanen yang tepat. Penerapan strategi terbaik dapat memberikan perbaikan dalam kondisi rantai pasok berdasarkan aspek benefit yaitu dapat meningkatan kualitas produk dan jumlah produksi sehingga meningkatkan keuntungan pelaku rantai pasok. Selain itu, berdasarkan aspek opportunity yaitu mampu meningkatkan penyerapan lapangan pekerjaan dan pengetahuan bagi petani sehingga petani mencapai kesejahteraan.

\section{KESIMPULAN DAN SARAN}

\section{Kesimpulan}

Stuktur rantai pasok bawang merah di Kabupaten Brebes memiliki kompleksitas anggota yang terlibat diantaranya petani, pedagang pengumpul, dan industri. Hasil penelitian terhadap evaluasi rantai pasok agroindustri bawang merah diketahui bahwa kinerja rantai pasok pada tingkatan pelaku rata-rata masih kurang baik.

Perhitungan nilai tambah menunjukan bahwa rasio nilai tambah tertinggi terdapat pada tingkat industri. Petani selaku pemeran kunci sebagai pemasok memiliki nilai tambah tertinggi kedua. Namun jika dibandingkan dengan tingkat keuntungan setiap pelaku, petani memiliki tingkat keuntungan paling rendah dibandingkan pelaku lainnya.

Hasil aksi mitigasi terbaik di setiap tingkat pelaku diketahui bahwa perlu adanya optimalisasi saprodi di tingkat petani, perbaikan SOP pascapanen dari mulai penggudangan, tenaga kerja terampil dan sarana penjemuran di tingkat pengumpul serta peningkatan kapasitas supplier dengan melakukan penilaian secara berkala di tingkat industri.

Alternatif strategi terbaik untuk peningkatan kinerja, nilai tambah dan mitigasi risiko rantai pasok agroindustri bawang merah yaitu dengan penerapan SOP budidaya dan dan pascapanen yang tepat.

\section{Saran}

Pengukuran kinerja dan mitigasi risiko rantai pasok perlu dilakukan secara berkala guna mengetahui kondisi rantai pasok sehingga permasalahan dapat terselesaikan secara efektif dan efisien. Pengukuran dapat dilakukan oleh pemerintah yang berkerjasama dengan pihak yang berkompetensi untuk memonitoring kondisi rantai pasok. Proses identifikasi risiko perlu dikaji secara mendalam agar mendapat opsi mitigasi yang sesuai kondisi rantai pasok. Untuk menghasilkan alternatif aksi mitigasi terbaik pada setiap pelaku rantai pasok perlu dilakukan focus group discussion antara pelaku dan pakar. Distribusi risiko dan nilai tambah rantai pasok agroindustri bawang merah padasetiap pelaku rantai pasok tidak seimbang, sehingga penelitian lanjutan yang dapat dilakukan yaitu penyeimbangan antara risiko dan nilai tambah agar tercipta rantai pasok yang berkeadilan. Penyusunan strategi peningkatan rantai pasok sebaiknya disusun untuk setiap pelaku guna memperoleh strategi peningkatan yang lebih spesifik.

\section{DAFTAR PUSTAKA}

Agami N, Saleh M, dan Rasmy M. 2011. A Hybrid Dynamic Framework for Supply Chain Performance Improvement. IEEE Systems Journal. 6(3): 469-478. doi: 10.1109/JSYST.2011.2177109.

Aldila FH, Fariyanti A, dan Tinaprilla N. 2015. Analisis profitabilitas usahatani bawang merah berdasarkan musim di tiga kabupaten sentra produksi di Indonesia. SEPA 11(2):249-260.

[BAPPENAS] Badan Perencanaan dan Pembangunan Nasional. 2015. Rencana Pembangunan Jangka Menengah Nasional (RPJMN) Bidang Pangan Dan Pertanian 2015-2019. Jakarta (ID): BAPENNAS.

Basuki RS. 2014. Identifikasi permasalahan dan analisis usahatani bawang merah di dataran tinggi pada musim hujan di kabupaten majalengka. Jurnal Hortikultura. 24(3):266275.

[BPS] Badan Pusat Statistika. 2016. Laporan Bulanan Data Ekonomi Sosial. Edisi 72. Jakarta (ID): BPS.

Christopher M, McKinnon A, Sharp J, Wilding R, Peck H, Chapman P, Ju“ ttner U, Bolumole Y. 2002. Supply Chain Vulnerability. United Kingdom (UK): Cranfield University.

Chopra S dan Meindl P. 2013. Suplay Chain Management: Strategy, Planning, and Operation. 3rd ed. New Jersey (US): Pearson Prentice Hall ${ }^{\mathrm{TM}}$.

El-Sayed AFM, Dickson MW, El-Naggar GO. 2015. Value chain analysis of the aquaculture feed sector in Egypt. Aquaculture. 437 92-101. doi: 10.1016/j.aquaculture.2014.11.033.

Frumkin P dan Keating EK. 2011. Diversification reconsidered: the risks and rewards of revenue concentration. Journal of Social Entrepreneurship. 2(2): 151-164. doi: 10.1080/19420676.2011.614630.

Hidayat S, Marimin, Ani S, Sukardi, Mohamad Y. 2012. Model identifikasi risiko dan strategi peningkatan nilai tambah pada rantai pasok kelapa sawit. Jurnal Teknik Industri. 14(2):89-96.

Insani DK dan Perdana T. 2014. Rancang bangun model sistem pembiayaan rantai pasok agribisnis pada komoditas bawang merah (allium ascalonicum l.) Di Kabupaten Brebes Jawa Tengah. Journal Agricultural Science. 1 (4): 154-166 (2014). 
Kamalahmadi M dan Parast MM. 2016. A review of the literature on the principles of enterprise and supply chain resilience: Major findings and directions for future research. International Journal Production Economics. Elsevier 171 116-133. doi: 10.1016/j.ijpe.2015.10.023.

[Kemendag] Kementrian Perdagangan. 2013. Tinjauan pasar bawang merah Edisi : Bawang Merah/Nov/2013. Jakarta (ID): Kemendag.

[Kementan] Kementrian Pertanian. 2015. Statistik Konsumsi Pangan Tahun 2015. Jakarta (ID): Kementan

Laudon KC dan Laudon JP. 2007. Sistem Informasi Manajemen Mengelola Perusahaan Digital. Edisi 10. Jakarta (ID): Salemba Empat.

Marimin. 2008. Teknik dan Aplikasi Pengambilan Keputusan Kriteria Majemuk. Jakarta (ID): Grasindo Gramedia Widiasarana Indonesia.

Marimin dan Maghfiroh N. 2010. Aplikasi Teknik Pengambilan Keputusan dalam Manajemen Rantai Pasok. Bogor (ID): IPB Press.

Marimin dan Setiawan A. 2010. Analisis pengambilan keputusan manajemen rantai pasok bisnis komoditi dan produk pertanian. Jurnal Pangan. 19(2):169-188.

Monczka R, Trent RJ, dan Handfield RB. 2011. Purchasing and Supply Chain Management. Ed ke-5. Ohio, South-Western (US): Cengage Learning.

Manuj I dan Mentzer JT. 2008. Global suplai chain risk management strategies. International Journal of physical Distribution \& Logistic Management 38(3):192-223.

Palma-mendoza JA dan Nealiley R. 2014. Analitical hierarchy process and SCOR model to support supply chain re design. International Journal Information Management. 34(2014): 634-638.
Pujawan dan Geraldin LH. 2009. House of risk: a model risk management for proactive supply chain risk management. Business Process Management Journal. 15(6): 953-67 DOI:10.1108/14637150911003801.

Rachman T. 2013. Pengukuran kinerja scm. Jakarta (ID): Universitas Esa Unggul.

Rich KM, Ross RB, Baker AD, Negassa A. 2011. Quantifying value chain analysis in the context of livestock systems in developing countries. Food Policy. 36(2): 214-222. doi: 10.1016/j.foodpol.2010.11.018.

Saaty TL. 2005. Theory and Applications of the Analityc Network Process. Pittsburgh (PA): Ellsworth Avennue.

[SCC] Supply Chain Council. 2012. SCOR Supply Chain Operation Reference. United States (US).

Septiani W. 2016. Rancang bangun model manajemen risiko rantai pasok groindustri susu berbasis pengetahuan. [Disertasi]. Bogor (ID): Institut Pertanian Bogor

So MWC dan Sculli D. 2002. The role of trust, quality, value and risk in conducting ebusiness. Industrial Management \& Data Systems. 102(9): 503-13.

Svensson G. 2001. Perceived trust towards suppliers and customers in supply chains of the Swedish automotive industry. International Journal Physical Distribution \& Logistics Management. 31(9): 647-62.

Vorst VD. 2006. Performance Measurement in AgriFood Suplai-ChainNetworks: An Overview. Wageningen (NL): Springer. 